\title{
MONITORING CO DAN DETEKSI DINI KEBOCORAN GAS LPG PADA PERUMAHAN MENGGUNAKAN WIRELESS SENSOR NETWORK
}

\section{CO MONITORING AND LPG LEAKAGE EARLY DETECTION ON HOUSING USING WIRELESS SENSOR NETWORK}

\author{
Firdaus $^{1}$, Nur Ahriman ${ }^{2}$, Syakban Kurniawan ${ }^{3}$, Medilla Kusriyanto ${ }^{4}$ \\ 1,2,3,4 Jurusan Teknik Elektro, Fakultas Teknologi Industri, Universitas Islam Indonesia \\ ${ }^{1}$ firdaus@uii.ac.id, ${ }^{2}$ mnurahriman@gmail.com, ${ }^{3}$ awan.dwi@gmail.com, ${ }^{4}$ medilla@uii.ac.id
}

\begin{abstract}
Abstrak
Ancaman bahaya pada lingkungan perumahan antara lain berasal dari kebocoran tabung gas LPG dan pencemaran gas karbonmonoksida (CO). Gas $\mathrm{CO}$ sangat sulit dikenali oleh manusia dan jika masuk ke tubuh manusia pada konsentrasi tertentu akan berdampak buruk terhadap kesehatan. Untuk itu dibutuhkan suatu sistem yang mampu memonitor besarnya konsentrasi gas $\mathrm{CO}$ di dalam ruangan dan terintegrasi dengan deteksi dini kebocoran LPG. Pada penelitian ini, dirancang sistem monitoring CO dan deteksi dini kebocoran LPG berbasis wireless sensor network (WSN) dengan menggunakan standar komunikasi zigbee. Ada 3 titik WSN yang membentuk jaringan bertopologi bus dan star. Sensor yang digunakan adalah LM35DZ sebagai pembaca suhu, HSM 20-G sebagai pembaca kelembaban, TGS 2600 sebagai pembaca gas CO, dan MQ-4 sebagai detektor gas LPG. Data pembacaan node-node sensor terkumpul pada node kordinator yang terhubung pada server. Data pada server ditampilkan dalam bentuk tabel dan grafik kemudian dikirimkan kepada user menggunakan komunikasi G-Talk. Jangkauan pengiriman data antar node sejauh \pm 53 meter, dimana rata-rata error pembacaan sensor TGS 2600 sebesar 4,414 \%. Jarak yang ideal dan aman antara sensor dengan tabung gas LPG adalah $25 \mathrm{~cm}$, dan waktu untuk mendeteksi kebocoran gas LPG \pm 12 detik.
\end{abstract}

Kata kunci: monitoring, karbon monoksida, wireless sensor network, zigbee, TGS2600.

\begin{abstract}
Hazards in residential neighborhoods come from leakage of LPG and the carbon monoxide (CO) pollution. CO gas is very difficult to be recognized by humans and if it gets into the human body at a certain concentration will have a negative impact on health. For that we need a system that can monitor the amount of CO gas concentration and early detection of LPG leakage. This paper present the design of CO monitoring system and early detection of LPG leakage based on wireless sensor network (WSN) using zigbee communication standard. There are 3 WSN node that form bus and star topology. The sensor nodes consist of LM35DZ as temperature reader, HSM 20-G as humidity reader, TGS 2600 as readers of CO gas, and MQ-4 as LPG gas detector. Data from sensor nodes are collected at the coordinator node that connected to the server. Data on the server is displayed in the form of tables and graphs then it sent to the user use GTalk application. Range data transmission between nodes as far as \pm 53 meters, where the average error of TGS-2600 is $4.414 \%$. Ideal and safe distance between the sensor with LPG gas cylinder is $25 \mathrm{~cm}$ and time to detect leakage of LPG gas is \pm 12 seconds.
\end{abstract}

Keywords: monitoring, carbon monoxide, early detection, wireless sensor networks, zigbee.

\section{PENDAHULUAN}

Sumber pencemaran udara dapat berasal dari berbagai kegiatan, antara lain industri, transportasi, perkantoran, dan perumahan. Sumber pencemaran udara juga dapat disebabkan oleh 
berbagai kegiatan alam, seperti kebakaran hutan, gunung meletus dan gas alam beracun. Salah satu parameter dari pencemaran udara yaitu gas karbon monoksida (CO) yang terkandung dalam udara [1].

Karena sifatnya yang tidak berbau, tidak berwarna maka gas CO sangat sulit dikenali oleh manusia, untuk dapat mendeteksi gas $\mathrm{CO}$, dibutuhkan suatu sistem yang mampu memonitor kadar gas CO. Wireless Sensor Network (WSN) telah banyak digunakan untuk membuat sistem monitoring, misalnya monitoring kebocoran pada stasiun pengisian hidrogen[2], deteksi dini kebocoran gas yang bisa mengakibatkan ledakan besar [3]. Penelitian telah juga dilakukan pada sisi penghematan penggunaan energi pada WSN [4]. Salah satu protokol yang popular digunakan dalam WSN adalah ZigBee (IEEE 802.15) [5].

Penelitian sebelumnya dilakukan oleh Anggit Perdana [6] mengenai penggunaan sensor gas TGS 2442 sebagai pendeteksi kadar gas karbon monoksida (CO), hasil dari pembacaan sensor diolah menggunakan mikrokontroller ATMega8 kemudian ditampilkan pada LCD. Jika kadar CO melebihi batas yang ditentukan, sistem akan memberi peringatan dalam bentuk getar dan suara. Pada penelitian tersebut, deteksi gas $\mathrm{CO}$ hanya dapat dilakukan pada satu titik dan data hasil pembacaan sensor hanya ditampilkan pada LCD. Penelitian selanjutnya dilakukan oleh Irvan Adhi [7], menggunakan sensor MQ-7 untuk mendeteksi gas CO. Data keluaran sensor diolah menggunakan mikrokontroller AVR ATMega8535 kemudian ditampilkan pada LCD. Sama halnya dengan penelitian yang dilakukan oleh Anggit Perdana, data hasil pembacaan sensor hanya ditampilkan pada LCD, tidak terdapat sarana penyimpan log data sensor.

Hendhi [8] melakukan penelitian tentang monitoring temperatur, kelembaban, dan gas $\mathrm{CO}_{2}$. Sensor HSM-20-G digunakan sebagai sensor temperatur dan kelembaban, sensor MQ-135 digunakan sebagai sensor gas $\mathrm{CO}_{2}$. Data dari node dikirimkan ke server berupa komputer. Pada penelitian ini, sistem yang dibangun bersifat stand alone, hanya terdapat satu node sensor yang mengirimkan data pembacaan ke receiver, sehingga memiliki keterbatasan pada jarak pengiriman data dan jumlah titik pengambilan data. Telah dirancang alat yang mampu mendeteksi keberadaan gas LPG di udara. Sensor yang digunakan untuk mendeteksi keberadaan gas LPG dalam penelitian tersebut adalah sensor gas LPG TGS-2610. Alat ini mampu mendeteksi gas LPG dalam waktu 0,37 detik pada jarak minimum[9]. Telah pula dirancang alat ukur konsentrasi gas LPG di udara dalam satuan ppm.[10]

Pengembangan selanjutnya adalah melengkapi sistem dengan menambahkan aktuator untuk skenario aksi penyelamatan dengan cara mengeluarkan gas LPG yang ada di dalam ruangan mengunakan exhaust fan[11]. Kemudian ada penambahan sistem informasi kepada user melalui media SMS[12]. Namun sistem-sistem di atas didesain hanya untuk memonitor satu obyek atau satu node saja.

Jika pada penelitian-penelitian sebelumnya sistem hanya mampu memonitor satu titik dan satu parameter, maka penelitian ini membangun sebuah sistem yang mampu memonitor banyak titik dan dua parameter (CO, LPG) serta terintegrasi dengan jaringan internet, sehingga sistem bisa dimonitor dan dikendalikan dari jarak jauh. Penelitian ini menggunakan WSN untuk memonitor Gas Karbonmonoksida (CO) dan deteksi dini kebocoran LPG menggunakan jaringan bertopologi bus dan multipoint to point [13]. Pengambilan data dilakukan pada tiga titik, semua data pembacaan sensor akan ditampilkan pada $P C$ server dengan menggunakan pengembangan software visual basic, kemudian disimpan ke database. Sistem juga mampu mengirim informasi kepada user melalui jaringan internet menggunakan komunikasi G-Talk.

\section{PERANCANGAN SISTEM}

Perancangan sistem aplikasi wireless sensor network untuk monitoring gas CO dan deteksi dini kebocoran LPG ini meliputi perancangan perangkat keras (hardware) dan perancangan perangkat lunak (software). Secara umum sistem terdiri dari dua bagian, yaitu bagian node sensor dan bagian server. Bagian node sensor bertugas untuk membaca dan mengirimkan data, bagian server bertugas untuk mengumpulkan, mengolah, menampilkan data dan kemudian menyampaikan informasi ke user. 


\subsection{Perancangan Node Sensor}

Node sensor terdiri dari empat buah sensor, perangkat radio transmitter Xbee-PRO [14], mikrokontroller ATMega8, dan power supply. Sensor yang digunakan adalah sensor TGS 2600[15] sebagai pembaca kadar gas CO, sensor HSM 20-G [16] sebagai pembaca kelembaban, sensor LM35DZ [17] sebagai pembaca suhu, dan sensor MQ-4 sebagai detektor gas LPG, seperti terlihat pada Gambar 1. Data dari keempat sensor diolah oleh mikrokontroller, kemudian dikirim secara nirkabel oleh ZigBee Transceiver. Tiap node sensor memiliki alamat tertentu, sehingga bagian server akan mampu mengenali lokasi sumber data.

\subsection{Perancangan Jaringan Nirkabel}

Blok diagram perancangan jaringan nirkabel sistem untuk mengumpulkan data bisa dilihat pada Gambar 2. Pada sistem ini, digunakan 3 buah node sensor dan antar node saling terhubung membentuk topologi bus. Node pertama akan mengirim data pembacaan sensor 1 (S-1) kepada node kedua, node kedua mengirim data pembacaan sensor 2 (S-2) dan sensor 1 (S-1) kepada node ketiga, node ketiga mengirim semua data pembacaan sensor (S-1, S-2, dan S-3) kepada node keempat. Node keempat kemudian mengirimkan data tersebut ke server (Personal Computer) secara serial.

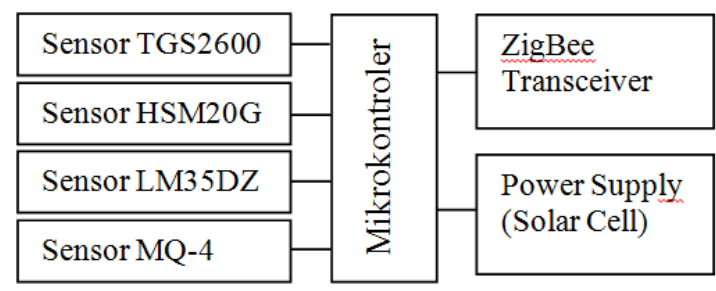

Gambar 1. Komponen-komponen pada node

sensor

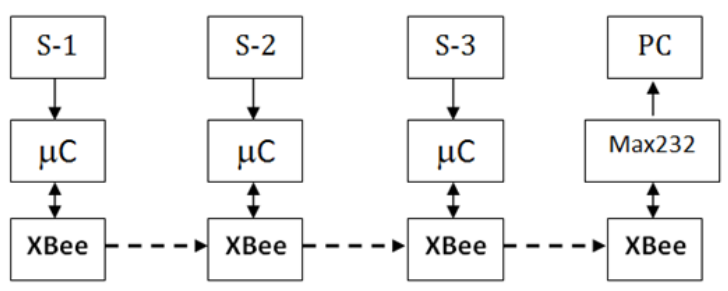

Gambar 2. Blok diagram sistem monitoring CO dan deteksi kebocoran gas LPG

\subsection{Perancangan Server}

Antarmuka pada server dibuat menggunakan software visual basic. Informasi kemudian disampaikan kepada user melalui jaringan mobile internet menggunakan aplikasi G-Talk. Google Talk (GTalk) adalah suatu layanan aplikasi berbasis web dari Google yang dibuat sebagai sarana untuk berkomunikasi melalui pesan instan dan VoIP. Layanan GTalk dibangun pada protokol open source yaitu XMPP (Extensible Messaging and Presence Protocol), standar IETF (Internet Engineering Task Force) untuk instant messaging.

\section{PEMBAHASAN}

Pengujian yang dilakukan meliputi pengujian sensor, pengujian pengiriman data secara nirkabel, dan pengujian penampilan data pada server serta penyampaian informasi kepada user. Pengujian sensor dilakukan untuk mengetahui tingkat rata-rata error pembacaan data. Pengujian pengiriman data dilakukan untuk mengetahui jarak maksimum pengiriman data dan tingkat keberhasilan pengiriman data dengan beragam skema pengiriman dan topologi jaringan.

\subsection{Pengujian Sensor Gas CO TGS 2600}

Sebelum melakukan pengukuran terhadap konsentrasi gas $\mathrm{CO}$ dengan menggunakan sensor TGS 2600, ada beberapa langkah yang harus dilakukan terlebih dahulu. Langkah pertama adalah mencari hubungan antara Rs/Ro dengan konsentrasi gas CO yang terdapat pada grafik standard karakteristik sensor dengan menggunakan regresi polinomial. Model regresi polinomial dipilih karena melihat bentuk kurva yang terdapat pada grafik standar karakteristik lebih mendekati bentuk kurva polinomial. Dari perhitungan yang telah dilakukan, didapatkan 2 buah persamaan untuk menentukan nilai konsentrasi gas CO. Persamaan yang didapatkan yaitu: 
$p p m=56,7 x^{2}-133 x+77,8$ untuk $1 \geq R s / R o \geq 0,75$

(1)

ppm $=322 x^{2}-573 x+256,7$ untuk $0,75 \geq R s / R o \geq 0,36$

(2)

Variabel $x$ adalah nilai Rs/Ro. Langkah kedua adalah menentukan nilai Rs dan Ro dari sensor. Rs merupakan nilai hambatan yang berubah-ubah saat sensor mendeteksi adanya paparan gas CO, sedangkan Ro merupakan hambatan yang nilainya tetap. Ro merupakan konstanta pembagi dalam perhitungan untuk mendapatkan nilai ppm. Nilai Ro didapatkan dengan cara mengkondisikan sensor pada suhu $20 \pm 2^{\circ} \mathrm{C}$ dan kelembaban $65 \pm 5 \%$. Setelah dikondisikan pada suhu dan kelembaban tersebut, kemudian dilakukan pengukuran terhadap nilai tegangan keluaran sensor. Suhu yang digunakan dalam pengujian sensor ini adalah $21^{\circ} \mathrm{C}$ dan kelembaban $62 \%$. Dari pengujian yang telah dilakukan diperoleh prosentasi error rata-rata pembacaan sensor gas CO adalah 4,414 \%. Hasil pengujian sensor TGS 2600 dapat dilihat pada tabel 1.

\subsection{Pengujian Sensor Suhu}

Sensor suhu LM35DZ memiliki karakteristik dimana setiap derajat yang terbaca diwakili nilai tegangan keluaran sebesar $10 \mathrm{mV}$. Pengujian sensor suhu ini menggunakan LCD sebagai penampil data hasil pembacaan. Dari pengujian yang telah dilakukan, diperoleh prosentasi rata-rata error sebesar $1,91 \%$ pada node $1,1,9 \%$ pada node 2 dan $2,01 \%$ pada node 3 . Hasil pengujian dapat dilihat pada tabel 2.

Tabel 1. Hasil Pengujian Sensor CO

\begin{tabular}{|l|c|c|c|}
\hline \multirow{2}{*}{ No } & \multicolumn{2}{|c|}{ Sensor TGS 2600 } & Datasheet \\
\cline { 2 - 4 } & $\mathbf{R s / R o}$ & $\begin{array}{c}\text { Kadar CO } \\
\text { (ppm) }\end{array}$ & $\begin{array}{c}\text { Kadar CO } \\
\text { (ppm) }\end{array}$ \\
\hline 1 & 0,90 & 3,96 & 4 \\
\hline 2 & 0,86 & 5,74 & 5 \\
\hline 3 & 0,84 & 5,81 & 6 \\
\hline 4 & 0,79 & 7,79 & 8 \\
\hline 5 & 0,77 & 8,90 & 9 \\
\hline 6 & 0,75 & 9,64 & 10 \\
\hline 7 & 0,65 & 16,64 & 20 \\
\hline 8 & 0,58 & 26,95 & 30 \\
\hline 9 & 0,52 & 40,41 & 40 \\
\hline 10 & 0,48 & 51,63 & 50 \\
\hline 11 & 0,45 & 61,37 & 60 \\
\hline 12 & 0,42 & 71,94 & 70 \\
\hline 13 & 0,4 & 79,91 & 80 \\
\hline 14 & 0,38 & 88,52 & 90 \\
\hline 15 & 0,36 & 97,06 & 100 \\
\hline
\end{tabular}

Tabel 2 Hasil Pengujian Sensor Suhu

\begin{tabular}{|c|c|c|c|c|}
\hline \multirow[b]{2}{*}{ No } & \multicolumn{3}{|c|}{ Suhu Sensor $\left({ }^{\circ} \mathbf{C}\right)$} & \multirow{2}{*}{$\begin{array}{c}\text { Suhu } \\
\text { Thermometer } \\
\left({ }^{\circ} \mathrm{C}\right)\end{array}$} \\
\hline & Node 1 & Node 2 & $\begin{array}{c}\text { Node } \\
\mathbf{3}\end{array}$ & \\
\hline 1 & 21,23 & 20,66 & 20,76 & 21 \\
\hline 2 & 22,48 & 21,14 & 21,70 & 22 \\
\hline 3 & 23,46 & 22,58 & 22,65 & 23 \\
\hline 4 & 25,90 & 25,46 & 25,48 & 25 \\
\hline 5 & 27,37 & 26,42 & 26,89 & 27 \\
\hline
\end{tabular}

Tabel 3 Hasil Pengujian Sensor Kelembaban

\begin{tabular}{|l|c|c|c|c|}
\hline \multirow{2}{*}{ No } & \multicolumn{2}{|c|}{ Kelembaban Sensor (\%) } & Kelembaban \\
\cline { 2 - 5 } & Node 1 & $\begin{array}{c}\text { Node } \\
\mathbf{2}\end{array}$ & Node 3 & $\begin{array}{c}\text { Higrometer } \\
(\boldsymbol{\%})\end{array}$ \\
\hline 1 & 61,63 & 55,89 & 60,76 & 58 \\
\hline 2 & 63,76 & 59,42 & 62,52 & 60 \\
\hline 3 & 66,78 & 61,93 & 64,80 & 62 \\
\hline 4 & 71,18 & 67,67 & 69,11 & 66 \\
\hline 5 & 74,44 & 71,60 & 73,54 & 70 \\
\hline
\end{tabular}

\subsection{Pengujian Sensor Kelembaban HSM 20-G}

Pengujian dilakukan dengan membandingkan nilai pembacaan sensor kelembaban dengan nilai pembacaan higrometer. Untuk mendapatkan nilai kelembaban yang berbeda-beda, maka pengujian dilakukan pada waktu dan lokasi yang berbeda. Pengujian dilakukan pada waktu siang, malam dan dini hari, sedangkan lokasi pengujian yaitu pada area indoor dan outdoor. Dari pengujian yang telah dilakukan, diperoleh nilai rata-rata error pembacaan sensor sebesar $6,50 \%$ pada node $1,1,54 \%$ pada node 2 dan 3,53\% pada node 3 . Hasil pengujian sensor kelembaban dapat dilihat pada tabel 3. 


\subsection{Pengujian Sensor Gas LPG MQ-4}

Pengujian sensor gas MQ-4 dilakukan dengan cara menyemprotkan gas LPG ke dekat sensor. Ketika gas disemprotkan ke dekat sensor, maka sensor akan langsung mendeteksi keberadaan gas tersebut. Sensor ini mempunyai nilai resistansi Rs yang akan berubah bila terkena gas LPG. Nilai Rs akan semakin turun bila mendeteksi gas LPG. Nilai Rs dapat dicari dengan menggunakan persamaan berikut.

$$
\mathrm{Rs}=\frac{\mathrm{Vc}}{\mathrm{VRL}-1} \times \mathrm{RL}
$$

Hasil pengukuran resistansi sangat dipengaruhi oleh tegangan $\mathrm{V}_{\mathrm{RL}}$ dari sensor. Tabel 4 menunjukan hasil pengukuran tegangan $\mathrm{V}_{\mathrm{RL}}$ dan Rs dari sensor gas MQ-4 ketika mendeteksi gas LPG. Cara untuk menentukan konsentrasi gas dilakukan dengan melihat referensi tabel data yang didapat dari datasheet sensor gas MQ-4. Gambar 3 menunjukkan grafik perbandingan antara sensor resistance ratio (Rs/Ro) dengan gas concentration dari sensor gas MQ-4. Grafik tersebut bersifat logaritmik, hal ini dapat diketahui dari skalanya.

Tabel 4 Tegangan dan Rs Sensor Gas MQ-4

\begin{tabular}{|c|c|c|c|}
\hline $\begin{array}{c}\text { Tegangan } \\
\left(\mathbf{V}_{\text {RL }}\right)\end{array}$ & Rs $(\mathbf{\Omega})$ & $\begin{array}{c}\text { Tegangan } \\
\left(\mathbf{V}_{\text {RL }}\right)\end{array}$ & Rs $(\mathbf{\Omega})$ \\
\hline 2,35 & 74074,07 & 3,52 & 39682,54 \\
\hline 2,63 & 61349,69 & 3,59 & 38610,04 \\
\hline 2,77 & 56497,18 & 3,68 & 34965,03 \\
\hline 3,01 & 49751,24 & 3,86 & 37313,43 \\
\hline 3,27 & 44052,86 & 4,02 & 33112,58 \\
\hline
\end{tabular}

Tabel 5 Hubungan Rs/Ro dengan Konsentrasi Gas LPG pada Sensor Gas MQ-4

\begin{tabular}{|l|c|}
\hline Rs/Ro & $\begin{array}{c}\text { Konsentrasi LPG } \\
\text { (ppm) }\end{array}$ \\
\hline 2,6 & 200 \\
\hline 1,6 & 1000 \\
\hline 0,9 & 5000 \\
\hline 0,73 & 10000 \\
\hline
\end{tabular}

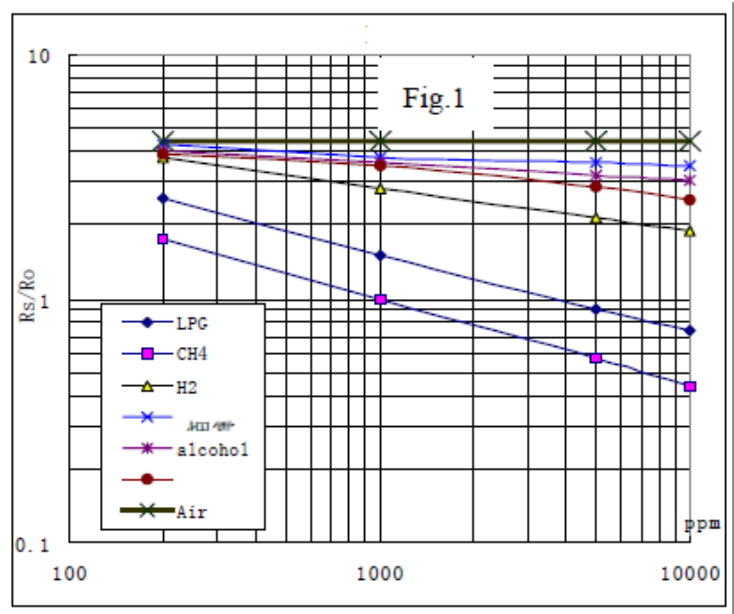

Gambar 3. Konsentrasi gas LPG vs Rs/Ro pada Sensor Gas MQ-4

\section{Grafik Rs/Ro vs Konsentrasi Gas LPG}

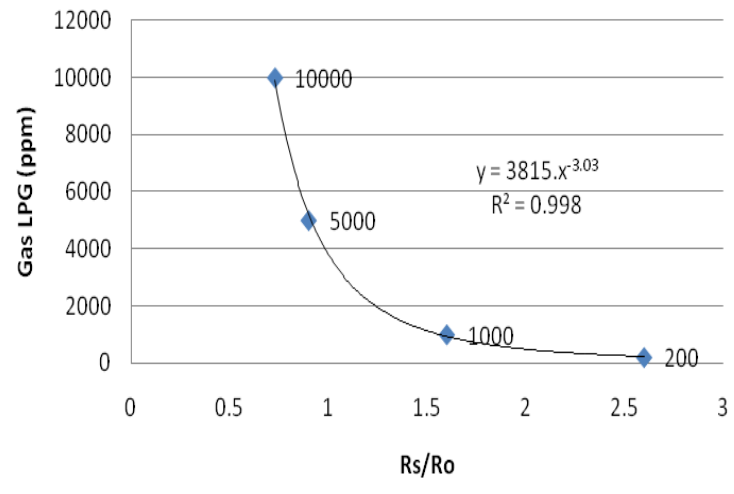

Gambar 4. Grafik Rs/Ro vs Konsentrasi Gas LPG

Berdasarkan grafik pada Gambar 3 maka dilakukan pengambilan data pada tiap titik yang ada pada grafik gas LPG dan dimasukkan pada Tabel 5. Dari Tabel 5 maka dibuatlah grafik yang baru untuk memperoleh persamaan garis. Gambar 4 menunjukkan grafik perbandingan konsentrasi gas LPG dengan Rs/Ro yang diperoleh menggunakan Ms.Excel. Dari grafik tersebut dapat dicari persamaan garisnya dengan fungsi add trendline pada Ms.Excel.

Dari Gambar 4 diperoleh persamaan garis $y=3815 x-3,03$. Sumbu $\mathrm{x}$ menunjukkan hasil perbandingan Rs/Ro, sedangkan sumbu y adalah konsentrasi gas LPG yang terdeteksi. Dengan persamaan ini dapat ditentukan konsentrasi gas yang dideteksi oleh sensor gas MQ-4 dengan melibatkan tegangan keluaran dari sensor. Kemudian dari persamaan (3) akan didapatkan Rs. Rs akan dibandingkan dengan Ro yang sudah didapatkan yaitu sebesar 33909,8 
$\Omega$. Cara kalibrasi sensor gas MQ-4 adalah dengan membandingkan nilai ppm yang diperoleh dari hasil pengukuran alat dengan grafik datasheet. Tabel 6 merupakan perbandingan data konsentrasi gas LPG yang diperoleh dari hasil pengukuran alat dengan data yang diperoleh dari grafik datasheet sensor MQ-4.

\subsection{Pengujian Jarak Pengiriman Data}

Pengujian dilakukan dalam ruangan (indoor) untuk mengetahui jarak maksimum pengiriman data antar node. Data yang dikirimkan berupa data pembacaan sensor suhu LM35DZ. Pada pengujian ini node yang digunakan yaitu node 3 dan node 2 . Node 3 difungsikan sebagai transmitter dan node 2 difungsikan sebagai receiver. Berdasarkan pengujian yang telah dilakukan, didapatkan jarak maksimal pengiriman data yaitu sejauh $53 \mathrm{~m}$ dengan kondisi terdapat penghalang berupa pintu setebal $3 \mathrm{~cm}$ dan tembok setebal $27 \mathrm{~cm}$. Denah lokasi pengujian dapat dilihat pada gambar 5.

Tabel 6 Pengukuran Menggunakan Sensor

\begin{tabular}{|c|c|c|}
\hline $\begin{array}{c}\text { Hasil } \\
\text { Pengukuran } \\
\text { Alat (ppm) }\end{array}$ & $\begin{array}{c}\text { Datasheet } \\
(\mathbf{p p m})\end{array}$ & $\begin{array}{c}\text { Error } \\
(\%)\end{array}$ \\
\hline 210,92 & 200 & 5,46 \\
\hline 591,51 & 600 & 1,415 \\
\hline 918,36 & 1000 & 8,164 \\
\hline 5249,76 & 5000 & 4,995 \\
\hline 7501,22 & 7500 & 0,016 \\
\hline 9899,8 & 10000 & 1,002 \\
\hline \multicolumn{2}{|c|}{ Rata-rata } & 3,51 \\
\hline
\end{tabular}

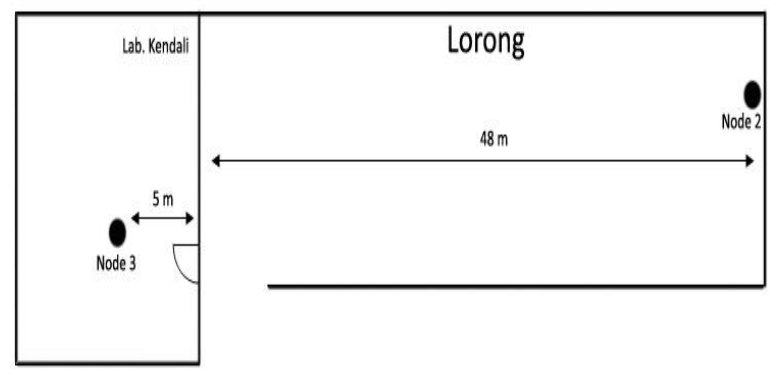

Gambar 5 Denah Lokasi Pengujian Jarak

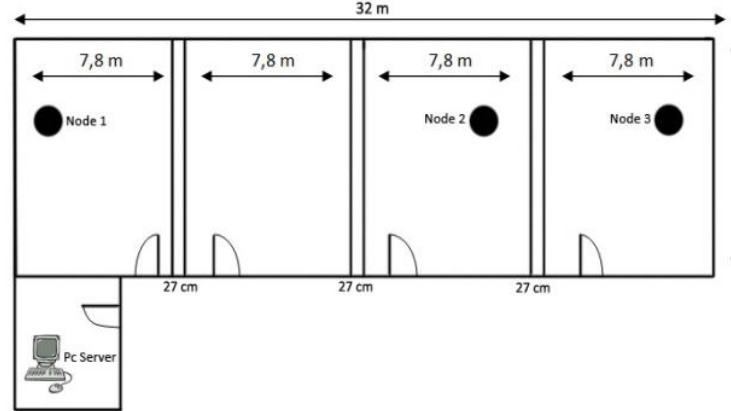

Gambar 6. Denah Lokasi Skenario 1

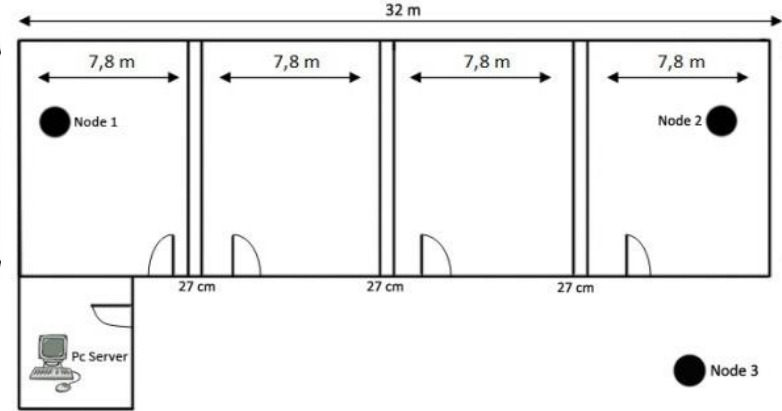

Gambar 7 Denah Lokasi Pengujian Skenario 2

\subsection{Pengujian Sistem Skenario 1}

Pada pengujian ini, ketiga node ditempatkan pada 3 ruangan yang berbeda dengan lantai gedung yang sama. Denah lokasi pengujian dapat dilihat pada gambar 6. Dapat dilihat pada gambar 6, antara node 3 dengan node 2 terdapat penghalang berupa tembok setebal $27 \mathrm{~cm}$ dan jarak dari kedua node adalah $11,87 \mathrm{~m}$, sedangkan posisi penempatan node 2 dan node 1 dibatasi oleh sebuah ruangan dan penghalang berupa 2 buah tembok yang masing-masing ketebalannya $27 \mathrm{~cm}$, jarak antara node 2 dengan node 1 yaitu 19,94 m. Dari pengujian yang telah dilakukan, semua data pembacaan node sensor dapat diterima dengan baik oleh receiver. Data hasil pengujian dengan skenario 1 dapat dilihat pada tabel 7.

Tabel 7 Hasil Pengujian Skenario 1

\begin{tabular}{|c|c|}
\hline Node & Status Pengiriman \\
\hline 3 ke 2 & Terkirim \\
\hline 2 ke 1 & Terkirim \\
\hline 1 ke receiver & Terkirim \\
\hline
\end{tabular}

Tabel 8 Hasil Pengujian Skenario 2

\begin{tabular}{|c|c|}
\hline Node & Status Pengiriman \\
\hline 3 ke 2 & Terkirim \\
\hline 2 ke 1 & Terkirim \\
\hline 1 ke receiver & Terkirim \\
\hline
\end{tabular}




\subsection{Pengujian Sistem Skenario 2}

Pada pengujian ini, denah lokasi pengujian dapat dilihat pada gambar 7. Pada pengujian skenario 2 ini, posisi antara node 3 dengan node 2 dibatasi oleh pintu kayu setebal $3 \mathrm{~cm}$. Untuk mengetahui kemampuan Xbee PRO dalam pengiriman data dengan media penghalang berupa pintu, maka saat pengujian dilakukan, pintu dalam keadaan tertutup. Antara node 2 dengan node 1 dibatasi oleh 2 buah ruangan dengan lebar 7,8 m dengan ketebalan tembok pada tiap ruangan $27 \mathrm{~cm}$, jarak antara kedua node $28,74 \mathrm{~m}$. Data hasil pengujian dengan skenario 2 dapat dilihat pada tabel 8 .

\subsection{Pengujian Sistem Skenario 3}

Pada pengujian dengan skenario 3 ini, setiap node dipasang pada ruangan dengan lantai yang sama. Denah lokasi pengujian dapat dilihat pada gambar 8. Pada pengujian kali ini, ketiga node akan mengirimkan data pembacaannya langsung ke receiver tanpa melalui repeater. Topologi jaringan yang dibentuk yaitu topologi multipoint to point. Semua node berhasil mengirimkan data ke server.

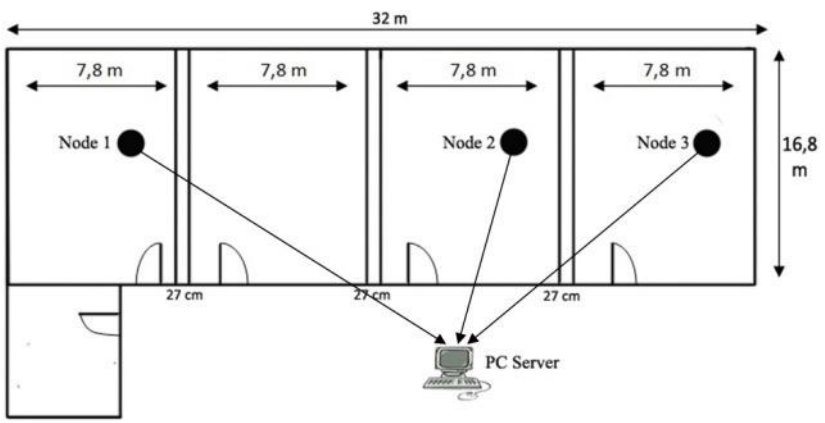

Gambar 8. Denah Lokasi Pengujian Skenario 5

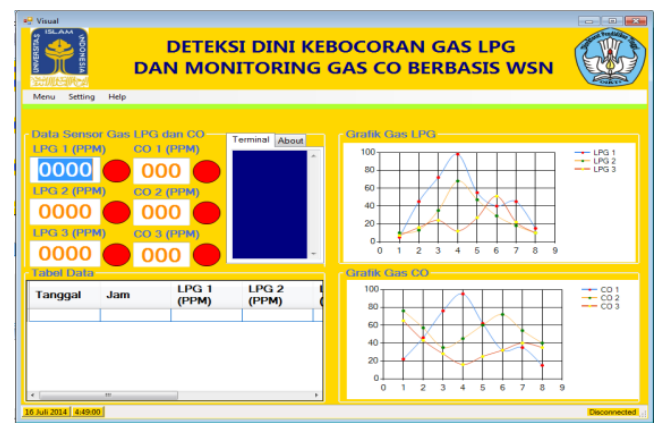

Gambar 9. Tampilan antarmuka sistem

Dengan menggunakan topologi multipoint to point, semua data pembacaan sensor dapat diterima dengan baik oleh receiver selama receiver berada dalam jangkauan gelombang radio yang dipancarkan setiap node. Salah satu kelebihan menggunakan topologi ini yaitu, apabila salah satu node mati, maka tidak akan mempengaruhi kerja node yang lainnya. Salah satu kelemahan dari penggunaan topologi ini yaitu jarak pengiriman data yang terbatas. Antarmuka pada server untuk menampilkan data bisa dilihat pada gambar 9 .

Jika monitoring dilakukan pada area indoor dengan jarak antar ruangan yang tidak begitu jauh, maka sebaiknya menggunakan topologi multipoint to point, namun apabila jarak antar ruangan yang akan dimonitor cukup jauh maka penggunaan topologi bus dapat menjadi solusi dalam melakukan monitoring. Dengan penambahan repeater, jarak pengiriman data dengan menggunakan XBee PRO akan semakin jauh.

\section{KESIMPULAN}

Sensor HSM 20-G memiliki sensitivitas yang berbeda-beda dalam pengukuran kelembaban. Rata-rata error pembacaan sensor HSM 20-G yaitu 6,50 \% pada node 1, 1,54 \% pada node 2 dan 3,53\% pada node 3. Rata-rata error pembacaan sensor suhu LM35DZ sebesar $1,91 \%$ pada node $1,1,9 \%$ pada node 2 dan $2,01 \%$ pada node 3 . Dengan menggunakan model regresi polinomial orde 2 , untuk pembacaan sensor TGS 2600, diperoleh error rata-rata jika dibandingkan terhadap datasheet sebesar 4,414 \% (jika menggunakan semua data) dan 2,12\% (jika menghilangkan 3 data pencilan). Dari hasil pengujian, jarak yang ideal dan aman antara transmitter dengan tabung gas elpiji adalah $25 \mathrm{~cm}$, dengan waktu untuk mendeteksi kebocoran gas $L P G \pm 12$ detik.

Jarak maksimum pengiriman data antar node pada area indoor dengan kondisi penghalang berupa pintu setebal $3 \mathrm{~cm}$ dan tembok setebal $27 \mathrm{~cm}$ yaitu $53 \mathrm{~m}$. Jaringan yang telah dirancang bekerja dengan baik selama node dapat menerima gelombang radio yang dipancarkan, data yang diterima pada receiver sesuai dengan data yang dikirimkan oleh transmitter. Pada 
topologi bus, apabila salah satu node mati maka sistem tidak akan bekerja, tidak ada data yang masuk ke bagian receiver. Hal ini bisa diatasi dengan menggunakan topologi multi point to point.

\section{Ucapan Terima Kasih}

Terima kasih pada Direktorat Jenderal Pendidikan Tinggi Indonesia and Direktorat Penelitian dan Pengabdian Masyarakat Universitas Islam Indonesia.

\section{DAFTAR PUSTAKA}

[1] Homan, C.S., Brogan, G.X., Carbon Monoxide Poisoning in Handbook of Medical Toxicology, $1^{\text {st }}$ ed., Little Brown and Co, Boston, 1993.

[2] Nakano, S., Goto, Y., Yokosawa, K., Tsukada, K., Hydrogen Gas Detection System Prototype with Wireless Sensor Networks, The 4th IEEE Conference on Sensors, Oct. 31 Nov. 3, Irvine, CA, USA, 2005.

[3] Somov, A., Baranov, A., Savkin, A., Ivanov, M, Calliari, L., Passerone, R., Karpov, E., and Suchkov, A., Energy-Aware Gas Sensing Using Wireless Sensor Networks, Proceedings of Wireless Sensor Networks: 9th European Conference, EWSN 2012, Trento, Italy, February 15-17, Springer , 2012.

[4] Somova, A., Baranovb, A., Savkinb, A., Spirjakinb, D., Spirjakinb, A., Passeronec, R., Development of wireless sensor network for combustible gas monitoring, Journal of Sensors and Actuators A: Physical vol. 171 page 398-405, Elsevier, 2011

[5] IEEE Computer Society, IEEE 802.15.1 Wireless medium access control (MAC) and physical layer (PHY) specifications for wireless personal area networks (WPAN), 2005.

[6] Perdana, A., Prototype of Monitoring and Warning System Gas Levels of Carbon Monoxide (CO) at Cars Cabin Based Microcontroller ATMega8, Undergraduate theses, Universitas Diponegoro, Semarang, 2011.

[7] Adhi, E., Design of Exhaust Emission Measurement, Case Study: Measurement of Gas Carbon Monoxide (CO), Undergraduate theses, Institut Teknologi Sepuluh November, Surabaya, 2011.

[8] Hermawan, H., Design of Network-Based Sensor Module RCM4510w On Weather Data Acquisition System, Undergraduate theses, Politeknik Elektronika Negeri Surabaya, 2012.

[9] Tarigan, Elfatra Daniel, "Perancangan Alat Pendeteksi Kebocoran Gas LPG Dengan Menggunakan Sensor TGS-2610 Berbasis Mikrokontroller AT89s51", Repository.usu.ac.id, 2010

[10] Nurhalimah, "Analisis Pengaruh Konsentrasi Gas LPG Menggunakan Sensor TGS 2610 Berbasis Mikrokontroler AVR ATMega8535", Repository.usu.ac.id, 2011

[11] Aji Kunto, "Air Flow Control System Based Microcontroller To Prevent Fires Due To LPG Gas Leak", Ejournal ITS, 2011

[12] Asep Saefullah, Hadi Syahrial, Ari Santoso, "Pendeteksi Kebocoran Tabung Gas LPG Menggunakan Mikrokontroller AT89s2051 Melalui Handphone Sebagai Media Informasi", Seminar Nasional Teknologi Informasi \& Komunikasi Terapan 2012 (Semantik 2012) ISBN 979 - 26 - 0255 - 0, Semarang, 23 Juni 2012

[13] Faludi, R., Building Wireless Sensor Network, O’Reilly Media, 2010.

[14] Digi International, Datasheet XBee PRO 802.15.4, www.digi.com (Januari 2013)

[15] Figaro, Datasheet Sensor TGS 2600, www.figarosensor.com (Januari 2013)

[16] Cytron, Datasheet Sensor HSM 20-G, www.cytron.com.my (Januari 2013)

[17] Texas Instruments, Datasheet Sensor LM35DZ, www.ti.com (Januari 2013) 